\section{Profile of congenital rubella syndrome in Soetomo General Hospital Surabaya, Indonesia}

\author{
Dionisia Vidya Paramita, Nyilo Purnami \\ Department of Otorhinolaryngology- \\ Head Neck Surgery, Faculty of Medicine \\ Universitas Airlangga/General Hospital \\ Dr. Soetomo, Surabaya, Indonesia
}

\begin{abstract}
Background: Definition of Congenital Ruben Syndrome (CRS): a disease caused by rubella virus infection. Routine surveillance of CRS is part of a government program in documenting the incidence of CRS so that infants with CRS are diagnosed promptly and receive appropriate care.

Objective: This study aims to report the profile of CRS patients 2015 in Audiology Outpatient General Hospital Dr. Soetomo Surabaya.

Method: A descriptive study from CRS surveillance data for the period from January $1^{\text {st }}$ until December $31^{\text {rd }}, 2015$. Data was from Infants who came to the Audiology Outpatient General Hospital Dr. Soetomo Surabaya and did hearing and serological examination.
\end{abstract}

Results: A total of 65 infants were involved in surveillance. The highest number of patients was the age group $1-<3$ years (21 patients, 31.2\%). A total of 36 patients $(55.4 \%)$ were male, 45 babies $(69.2 \%)$ were suspected of suffering from CRS with 2 infants $(3.1 \%)$ classified as a laboratory-confirmed CRS. Hearing abnormalities were found in 36 infants $(55.4 \%)$. Bilateral hearing loss was found in 23 infants $(35.4 \%)$ and unilateral in 13 infants (20\%).

Conclusions: This study shows that hearing impairment is the most common clinical symptom with most bilateral hearing loss. The supervision still needs to be continued to capture more CRS cases in the community and effective supervision to detect hearing impairment early.

\section{Introduction}

Congenital rubella syndrome (CRS) is a collection of several congenital abnormalities including hearing impairment, cataracts, and cardiac abnormalities. This syndrome was caused by rubella virus infection in pregnant women, especially during the first trimester. The most common clinical manifestation of CRS is hearing impairment, which is around $70-90 \%$ of all cases of disability due to CRS. ${ }^{1,2}$

As many as 100,000 infants every year in the world were born with CRS. The highest numbers were in Southeast Asia (48\%) and Africa (38\%). ${ }^{3}$ World Health Organization (WHO) in 2012-2020 has done strategic plan to achieve a world free of measles, rubella and CRS. This plan can be achieved by conducting surveillance. The CRS surveillance focuses on identifying infants less than one-year-old. Through surveillance, infants with CRS can be diagnosed immediately and get appropriate treatment. ${ }^{3,4}$ CRS surveillance in Indonesia has begun to be conducted in eleven hospitals. There were Dr. Cipto Mangunkusumo Hospital, Anak dan Bunda Harapan Kita Hospital, Dr. Hasan Sadikin Hospital, Cicendo Eye Hospital, Dr. Sardjito Hospital, Dr. Kariadi Hospital, Dr. Soetomo Hospital, Sanglah Hospital, Dr. Wahidin Sudirohusodo Hospital, Dr. M. Hoesin Hospital, and H. Adam Malik Hospital. ${ }^{5}$

This study aims to determine the profile of tinnitus sufferers in the Audiology Outpatient Unit of OtorhinolaryngologyHead Neck Surgery Departement, Dr. Soetomo general hospital Surabaya in 2015.

\section{Materals and Methods}

The design of this study was retrospective descriptive. Data samples were taken from the CRS surveillance form in the Audiology General Hospital outpatient unit Dr. Soetomo Surabaya during the period between January $1^{\text {st }}$ and December $31^{\text {st }}$ 2015. The sample included infants less than one year old who came for an examination at the audiology clinic Dr. General Hospital Soetomo Surabaya and had a hearing and serological examination recorded on the CRS case surveillance form. The data included in the CRS case surveillance form are patient identity, clinical symptoms, laboratory examinations, and classification. Clinical symptoms of CRS consist of clinical symptoms of group A and group B. Clinical symptoms of group A include congenital heart disease, congenital cataracts, congenital glaucoma, retinopathy pigmentosum, and hearing inpairment. Clinical symptoms of group B are purpura, microcephaly, meningoencephalitis, jaundice 24 hours post partum, splenomegaly, developmental delay, and radiolucent bone disease. $^{3,6}$

Laboratory criteria for confirming CRS cases, namely the detection of anti-rubella $\operatorname{IgM} \geq 1 \mathrm{IU} / \mathrm{mL}$ or the presence of anti-rubella $\mathrm{IgG}$ with a level of $\geq 10 \mathrm{U} / \mathrm{mL}$ in at least two examinations in the 6-12 month age
Correspondence: Nyilo Purnami. Department of Otorhinolaryngology- Head Neck Surgery, Faculty of Medicine Universitas Airlangga/General Hospital Dr. Soetomo Surabaya, Jl. Mayjen Prof. Dr. Moestopo No.6-8, Airlangga, Kec. Gubeng, Kota Surabaya, Jawa Timur, Indonesia 60286. Tel: +62815510081

E-mail: nyilo@fk.unair.ac.id

Key words: Congenital rubella syndrome, surveillance, epidemiology, infant.

Contributions: The authors contributed equally.

Conflict of interest: The authors declare no potential conflict of interest.

Funding: None.

Acknowledgements: The authors thank all those who helped in completing this study.

Conference presentation: Part of this paper was presented at International Conference of Infectious Diseases, Biothreats and Military Medicine (INSBIOMM).

Received for publication: 17 February 2020. Accepted for publication: 1 July 2020.

This work is licensed under a Creative Commons Attribution-NonCommercial 4.0 International License (CC BY-NC 4.0).

${ }^{\circ}$ Copyright: the Author(s), 2020

Licensee PAGEPress, Italy

Infectious Disease Reports 2020; $12($ (s1):8718 doi:10.4081/idr.2020.8718

range without rubella vaccine. Case classification for CRS surveillance purposes is based on clinical, epidemiological features, and laboratory data. Case definitions for surveillance are listed in Table 1. The findings of each case suspected of CRS should be classified according to an algorithm determined by WHO based on the age group $<6$ months and ages between 6-12 months. $^{3}$

All records are taken from the patient's medical record, then recorded in the data collection sheet and then tabulated. Data processing are then presented in tabular and narrative form.

\section{Results}

During the surveillance period between January $1^{\text {st }}$ and December $31^{\text {st }} 2015,65$ samples were obtained. The youngest patient was 13 days old and the oldest was 10 months old. The number of patients with $<1$ month age group was $18(27.7 \%)$, 
while the $1-3$ months age group consisted of 21 infants $(32.3 \%)$. The number of the 3 6 months age group included 17 infants (26.2\%) and patients with 6-12 month age group were only $(13.8 \%)$.

A total of 36 samples $(55.4 \%)$ were male, while 29 samples $(44.6 \%)$ were female. The ratio of men to women is 1.2:1. Most of the patients' address were in Surabaya, as many 39 infants (60\%), 20 infants $(30.8 \%)$ from other cities in East Java, 4 infants (6.2\%) from Madura, 1 infant from Central Java, and 1 infant from Central Kalimantan.

Based on Table 1, the most common clinical symptom of group A was hearing impairment, in 36 infants (55.4\%). Bilateral hearing loss affected 23 infants (35.4\%) and unilateral hearing loss affected 13 infants $(20 \%)$. Congenital heart disease was the second most common symptoms, present in 17 patient $(26.2 \%)$. The most common clinical symptom of Group B is 24-hour post partum jaundice, in 43 patients $(66.2 \%)$.

Based on Table 2, the serologic test results were found that 2 samples $(3.1 \%)$ were obtained with positive results in patients with 1-6 months age group. Antirubella $\operatorname{IgG}$ examination showed positive results in 35 samples with 2 samples (3.1\%) in patients with 6-12-month age group.

The CRS case classification was listed in Table 3. A total of 45 infants $(69.2 \%)$ were suspected of CRS. 21 infants $(46.7 \%)$ suspected of CRS were female and 24 infants $(53.3 \%)$ were male. Two infants $(3.1 \%)$ were included in the definitive classification of CRS.

\section{Discussion}

A surveillance system involving all hospitals as well as other health services needs to be established to determine the burden of the diseases due to CRS. The resources needed to build a CRS surveillance system

Table 1. Clinical symptoms of CRS.

\begin{tabular}{lccc} 
& Yes (\%) & No (\%) & Don't know (\%) \\
Group A clinical symptoms & & & \\
Congenital heart disease & $17(26.2)$ & $24(36.9)$ & $24(36.9)$ \\
Congenital cataract & $8(12.3)$ & $26(40)$ & $31(47.7)$ \\
Congenital glaucoma & $1(1.5)$ & $30(46.2)$ & $34(52.3)$ \\
Retinopati pigmentosum & $4(6.2)$ & $27(41.5)$ & $34(52.3)$ \\
Hearing impairment & $36(55.4)$ & $16(24.6)$ & $13(20)$ \\
Group B clinical symptoms & & & \\
Purpura & $0(0)$ & $43(66.2)$ & $22(33.8)$ \\
Microcephaly & $5(7.7)$ & $43(66.2)$ & $17(26.1)$ \\
Meningoencephalitis & $0(0)$ & $41(63.1)$ & $24(36.9)$ \\
Ikteus 24 hours post partum & $43(66.2)$ & $16(24.6)$ & $6(9.2)$ \\
Splenomegaly & $0(0)$ & $32(49.2)$ & $43(50.8)$ \\
Developmental delay & $7(10.8)$ & $18(27.7)$ & $42(61.5)$ \\
Radiolucent bone disease & $1(1.5)$ & $22(33.8)$ & $22(33.8)$ \\
Purpura & $0(0)$ & $43(66.2)$ & \\
\hline
\end{tabular}

Yes: clinically related symptoms occur. No: no associated clinical symptoms. Don't know: not known to have clinically related symptoms.

Table 2. Anti-rubella IgM and IgG test results.

\begin{tabular}{lcccc} 
& $<1$ month & $\mathbf{1 - 6}$ month & $\mathbf{6 - 1 2}$ month & Total (\%) \\
IgM anti-rubella & & & & \\
Positive & 0 & 2 & 0 & $2(3.1)$ \\
Negative & 12 & 22 & 7 & $41(63.1)$ \\
Don't know & 6 & 14 & 2 & $22(33.8)$ \\
IgG anti-rubella & & & & \\
Positive & 11 & 21 & 2 & $34(52.3)$ \\
Negatie & 1 & 4 & 5 & $10(15.4)$ \\
Don't know & 6 & 13 & 2 & $21(32.3)$ \\
\hline
\end{tabular}

Information : IgM + : $\geq 1 \mathrm{IU} / \mathrm{ml}$; IgM - : $<1 \mathrm{IU} / \mathrm{ml} ;$ IgG + : $\geq 10 \mathrm{IU} / \mathrm{ml}$; IgG - : $<10 \mathrm{IU} / \mathrm{ml}$; Don't know: it is not known whether serology has been carried out.

Table 3. Classification of CRS.

\begin{tabular}{|c|c|c|c|c|c|}
\hline $\begin{array}{l}\text { Suspected CRS } \\
\text { Clinically confirmed CRS }\end{array}$ & $\begin{array}{l}\text { Laboratory classified } \\
\text { confirmed }\end{array}$ & $\begin{array}{l}\text { Discarded } \\
\text { CRS }\end{array}$ & Can't be CRS & Not suspected CRS & Can't be classified \\
\hline $12(18.5 \%)$ & $2(3.1 \%)$ & $24(36.9 \%)$ & $7(10.8 \%)$ & $11(16.9 \%)$ & $9(13.9 \%)$ \\
\hline
\end{tabular}

Table 4.Definition of CSR cases for surveillance purposes ${ }^{3}$

\begin{tabular}{|c|c|}
\hline Case classification & Definition \\
\hline Suspect CRS & $\begin{array}{l}\text { Every infant }<1 \text { years old with } \geq 1 \text { clinical symptomps from group A and no other obvious cause or mother has a history } \\
\text { of suspected rubella or definitely rubella during pregnancy whether the infant has symptoms or not }\end{array}$ \\
\hline Clinically confirmed CRS & $\begin{array}{l}\text { Infants }<1 \text { year old with two clinical symptoms from group A or one symptom from group A and one symptom from group } \\
\text { B and no laboratory confirmation yet }\end{array}$ \\
\hline Laboratory confirmed CRS & Infants with clinical CRS that meet CRS laboratory criteria \\
\hline Congenital rubella infection & Infants $<1$ year old who do not meet CRS clinical criteria, but positive anti rubella IgM test results \\
\hline Discarded CRS & $\begin{array}{l}\text { Infants suspected of CRS with negative laboratory results for rubella virus infection, or infants suspected of CRS who do not } \\
\text { meet CRS clinical criteria (for example, there are only } 1 \text { symptom of group A), have not been adequately tested, and have no } \\
\text { history of being conceived by mothers who are laboratory confirmed rubella during pregnancy }\end{array}$ \\
\hline
\end{tabular}


to female ratio of $1.1: 1{ }^{7}$ Hearing impairment was the most common clinical symptom of group A and was found in 36 infants (55.4\%). Bilateral hearing impairment occurs more often than unilateral. Research in London stated that bilateral hearing impairment in CRS infants was $61 \%$ more frequent than unilateral hearing impairment. ${ }^{8}$ Research in the United States stated that hearing impairment was the most frequent sympton, reported in $73 \%$ in infants suspected of CRS. Different results were obtained in research in Myanmar, where congenital heart abnormalities was the most frequent symptom $(72 \%)$. This can be explained by the limitations in diagnosing hearing impairment in young infants as hearing impairment can appear late: routine checks are needed on infants suspected of CRS. ${ }^{10}$

Positive anti rubella IgM results were found in 2 infants $(3.1 \%)$ in the 1-6 month age group and anti rubella IgG results in the 6-12 month age group were also obtained in 2 infants $(3.1 \%)$. Both infants with positive IgM results can be classified as definite CRS, but both infants with positive IgG results at the age of 6-12 months cannot be classified with certainty CRS because no IgG tests have been performed again. This result is different from research in Myanmar, which mentions positive IgM results in samples aged $<6$ months at $3.7 \%$, while positive $\mathrm{IgG}$ results aged 6-12 months at $12.3 \% .{ }^{10}$ This difference can be due to the higher number of infants aged 6-12 months in the research in Myanmar, amounting to $25 \%$ of the entire sample, while in this study they account for only $13.8 \%$ of the total amount.
The majority of the sample of this study can be categorized as suspected CRS $(18.5 \%)$ and whereas laboratory confirmed CRS was only $3.1 \%$. Similar results were obtained in a study in Fiji, which mentioned that most CRS cases were categorized as suspected CRS, with clinical CRS diagnosis in less than $20 \%$ of the cases. A total of 7 cases from all cases suspected CRS in this study could not be classified. This can be caused by obstacles in data collection due to the patient getting an examination from several related departments so as to enable the data to be filled in correctly.

\section{Conclusions}

This study shows that bilateral hearing impairment is the most common clinical symptom. The supervision still needs to be continued to capture more CRS cases in the community and effective supervision to detect hearing impairment early.

\section{References}

1. McLean H, Fiebelkorn A, Temte J, Wallace G. Prevention of measles, rubella, congenital rubella syndrome, and mumps, 2013. MMWR 2013;62:138

2. Banatvala J, Peckham C, editors. Rubella Viruses. 1st ed. Oxford: Elsevier; 2007.1-79 p.

3. World Health Organization. Strategic plan for measles elimination and rubella and congenital rubella syndrome con- trol in the South-East Asia Region 2014-2020. Available from: http://apps.searo.who.int/PDS_DOCS/ B5206.pdf

4. World Health Organization. Global measles and rubella strategic plan: 2012-2020. 2012 Available from: http://apps.who.int/iris/bitstream/ 10665/44855/1/978924

5. Kementerian Kesehatan Republik Indonesia. Pedoman surveilans CRS 2014. Jakarta 2014.

6. World Health Organization. Surveillance guidelines for measles, rubella, and congenital rubella syndrome in the WHO European region. 2012. Available from: http://www.euro.who.int/data/assets/pd f_file/0018/79020

7. Singh S, Bingwor F, Tayler-Smith K, et al. Congenital rubella syndrome in Fiji, 1995-2010. J Trop Med. 2013;2013.

8. Wild NJ, Sheppard S, Smithells RW, et al. Onset and severity of hearingloss due to congenital rubella infection. Arch Dis Child 1999;64:1280-3.

9. Ugnat AM, Grenier D, Thibodeau ML, Davis M. The Canadian Paediatric Surveillance Program: Celebrating 15 years of successful paediatric surveillance. Paediatr Child Health (Oxford) 2011;16:203-5.

10. Kyaw-Zin-Thant, Win-Mar-Oo, TheinThein-Myint, et al. Active surveillance for congenital rubella syndrome in Yangon, Myanmar. Bull World Health Organ 2006;022814:12-20. 